Article

\title{
Application of Nano High-Entropy Alloys to Reduce Energy Consumption and Wear of Copper Oxide and High-Grade Iron Ores in Heavy Mining Industries-A Case Study
}

\author{
Mohammadreza Heydartaemeh ${ }^{1, *(\mathbb{D})}$, Mohammad Karamoozian ${ }^{1}$ and Herman Potgieter ${ }^{2,3}$ \\ 1 Faculty of Mining, Petroleum and Geophysics, Shahrood University of Technology, \\ 3619995161 Shahrood, Iran; m.karamoozian@shahroodut.ac.ir \\ 2 School of Chemical and Metallurgical Engineering, University of the Witwatersrand, \\ 2050 Johannesburg, South Africa; H.Potgeiter@mmu.ac.uk \\ 3 Department of Natural Science, Faculty of Science and Engineering, Manchester Metropolitan University, \\ Manchester M15 6BX, UK \\ * Correspondence: m.heydartaeme@gmail.com or m.heydartaeme@shahroodut.ac.ir
}

Received: 23 October 2019; Accepted: 19 December 2019; Published: 23 December 2019

check for updates

\begin{abstract}
Problems relating to the abrasion of equipment is one of the most important issues in mining and associated industries. Hardening is a method of protecting metal equipment, metal tools, or important components against erosion, corrosion, and abrasion. This can be achieved by welding a thin layer of abrasion-resistant metal onto the surface of the work piece. The useful life of a piece of equipment or parts can be significantly increased by applying abrasion-resistant coatings, thereby reducing repair or replacement costs associated with damaged parts. This process is inexpensive in the production of parts and is often economically justifiable. This study focuses on measuring the abrasion resistance of a nano high-entropy alloy against copper oxide and high-grade iron ores. When a base alloy was coated with the nano high-entropy alloy, the abrasion indexes of iron and copper ores decreased from $0.0001647 \mathrm{~kg}$ to $0.0000908 \mathrm{~kg}$ and from $0.0001472 \mathrm{~kg}$ to $0.0000803 \mathrm{~kg}$, respectively. The standard deviation, repeatability, and reproducibility were calculated for the alloy steel blade covered with nano high entropy alloy (N-HEA), producing values of $0.00016,0.00047$, and 0.00040 , respectively, while a standard alloy steel blade exhibited values of $0.0003,0.00047$, and 0.00042 , respectively. High-entropy alloys and high-entropy nano-alloys have not been used as practical coatings in the mineral industry in any form to date. Utilizing high-entropy nano-alloys in this industry would introduce innovative alternatives for customers, thereby increasing competitive advantages and providing international markets and customers $=$ with the most efficient choices of operational materials.
\end{abstract}

Keywords: nano high-entropy alloys (N-HEAs); hard coatings; iron and copper ores; abrasion index; ball mills; rods; lining material

\section{Introduction}

Minimizing energy consumption is one of the most important issues for industries. In the world of economy and industry, saving energy by applying a balanced set of price and non-price measures to continually reduce energy has always been the most important goal to keep the industry wheel turning [1]. Various types of materials are used in each sector of the mining industry. In alloying, various elements are added to a main element to improve its properties. However, a new class of alloys with at least five basic elements of equal or similar atomic compositions has recently been 
created made [2]. Usually, the atomic percentage of each element is more than 5\%. The entropy of incorporation of these alloys is maximal, resulting in high-entropy alloys, also known as multi-element alloys. Unlike conventional alloys, the mechanical properties of high-entropy alloys are independent on their constituent elements. In fact, the type of structure is the determining parameter ultimately controlling the strength or hardness of the high-entropy alloy. High-entropy alloys have excellent properties [3], including high levels of hardness, fatigue resistance, and strength at ambient and high temperatures, as well as dramatic tensile properties [4]. The microstructure type and properties of high-entropy alloys depend on the types and amounts of constituent elements; careful selection of compounds and elements allow for a proportion of body-centered cubic (BCC) or face-centered cubic (FCC) solid solutions to be obtained, therefore giving the best mechanical and physical properties to the alloy.

Hard-facing is a method of protecting metal equipment, metal tools, or other important components to prevent wear [5], stress, and abrasion so that a thin layer of engineered (strong metal) metal that is wear-resistant is added onto the work piece surface (weak metal) [6]. In many industrial applications, parts with hard surfaces, but are still tough and impact-resistant, are essential. Some examples include camshafts, crankshafts, cogwheels, and other parts used in mineral processing plant equipment (wearing and crushing circuits). These components require very hard and wear-resistant surfaces [7-12], as well as a high level of toughness and impact-resistance in mineral processing circuits during operation.

Welding is the deposition of a filler on the surface of a work piece to obtain desired properties or dimensions that are typically used to extend the work life of a piece or to replace metal that has been worn or corroded. Some common welding methods employed for this purpose include arc welding with a hood electrode [13], submerged arc welding [14], arc welding with a powdered electrode [15], laser hard-facing [15], gas welding (flame) [13,15], metal arc welding with protective gas [13], flame welding with powder [15,16], gas tungsten arc welding [16], and plasma arc welding [17]. Some coatings are precipitated by gas or arc welding processes or by thermal spraying processes, and manual, semi-automatic, or automatic methods can be applied to any of these processes. Suitable fillers are available in various shapes and types, such as welding rods, coating electrodes, pastes, and powders.

Choosing a suitable alloy and a suitable hard coating to crush and scrub mineral equipment has always been a challenging issue in the process of economic production of alloying. Today, casting and molding of alloys such as FeCoNi, FeNiMo, SS304 [18], and D2 [19] are utilized in the manufacture of most mining equipment parts. By choosing a suitable coating and coating method, the base alloy of parts can be made of much cheaper materials.

High-entropy alloys [3,19-22] and high-entropy nano-alloys [23,24] have not been used as a practical coating in the mineral industry in any form so far. The extraordinary characteristics of high-entropy alloys in can be made us of in heavy industries [25-37] to produce unique compositions [38-45] and their behaviors and properties [46-48] can be manipulated to introduce innovative alternatives, such as filler metals [49], which are hard-facing [50-52] and wear resistant [53] to increase to shear failure, high cavitation erosion, and corrosion $[54,55]$. In general, the impact strength of hardened alloys decreases with increasing carbide content. In applications where impact resistance is very important, manganese austenitic steels can be used to repair parts [17]. The higher the number of alloying elements in the intermetallic compounds, the more complex the structure. Due to the limited solubility of the elements in the alloy, brittleness is increased [55,56].

High-entropy alloys are a group of materials that combine between 5 and 13 different elements with atomic percentages of 5-35\% [20,23,57]. The essence of high-entropy alloys is that it combines maximum static entropy with equal atomic ratios according to the Boltzmann entropy hypothesis [58]. The high strength of the solid solution allows for industrial applications of these high-strength alloys as high-temperature tools, molds, and components with high wear and oxidation resistance [17]. Mechanical alloying $[59,60]$ is a solid state-of-the-art method of producing nanocrystals $[23,24]$ with potential strategic applications [17]. In applications where impact resistance is very important, manganese austenitic steels can be used for component reconstruction [61]. Some coatings are used to 
resist abrasion, cavitation, corrosion, and friction and include a wide range of metals and their alloys, ceramics, cermets, carbides, and even low-friction plastics. The usual hardness of coatings varies from 20-70 Rockwell hardness (HRC) [16,62,63]. Metal surfaces are hardened by rapid freezing, where hard phases, such as chromium carbides, tungsten, titanium or tantalum, and hard oxide impurities, are added separately [64-66].

The choice of hardening alloy is based on two main factors, namely, wear rate and cost. However, other important factors, such as base metal type, deposition process, impact, corrosion, oxidation, etc., must also be considered. Hardened alloys are typically used as powders or coated rods, flax-coated rods, solid welds, and long powder-coated welds. The different methods of surface treatment are divided into several groups, including building up, buttering, cladding, and hard-facing. This project may be the first of its kind in terms of using high-entropy nano-alloys as coatings in the above-mentioned industry.

The statistical studies of standard deviation, repeatability, and reproducibility were performed to evaluate the accuracy of the bond abrasion index results $[67,68]$. Experimental data of each alloy were fitted and examined by calculation of the correlation factor $\left(R^{2}\right)$. Measurements regarding the standard alloy steel blade and alloy steel blade covered by N-HEA were calculated according to important statistical factors, such as standard deviation $(s)$, test deviation $(d)$, average standard deviation tests $\left(s_{\bar{x}}\right)$, standard deviation of repeatability $\left(S_{r}\right)$, and standard deviation of reproducibility $\left(S_{R}\right)$, among others.

To date, very few studies have been conducted on HEA containing Hf [50], and none on HEA containing Ba. This investigation explores the properties of HEA containing these two elements.

\section{Materials and Methods}

\subsection{High-Entropy Nano-Alloy Coating Method}

In this paper, hardening operations were performed using welding. The manufactured powder of the high-entropy FeMoCrNiBaHf nano-alloy was formed into a flux-cored electrode and used as a coating on a sample of mild steel using the Oxyfuel powder spray (OFP) method. After welding, the thickness of the coating was $4 \mathrm{~mm}$, as measured with a calipher, model IP 54 from the G.A.L. Gage company (Bridgman, MI, USA). The most common hard-facing processes associated with the type of consumables appropriate to them are presented in Table 1.

Table 1. Common hard-facing processes with different types of materials used in them [12].

\begin{tabular}{cc}
\hline Hardfacing Process & Consumable \\
\hline Oxyfuel/Oxyacetylene (OFW/OAW) & Bare cast or tubular rod \\
Shielded metal arc (SMAW) & Coated solid or tubular rod (stick electrode) \\
Oxyfuel powder spray (OFP) & Powder, tubular wire (flux-cored) \\
Gas-tungsten arc (GTAW) & Bare cast or tubular rod \\
Gas-metal arc (GMAW) & Tubular or solid wire \\
Flux-cored open arc & Tubular wire (flux-cored) \\
Submerged arc (SAW) & Tubular or solid wire \\
Plasma transferred arc (PTA) & Powder \\
Laser beam & Powder \\
\hline
\end{tabular}

\subsection{Characteristics of High-Entropy Nano-Alloy}

The nanoscale properties and X-ray diffraction data of this experimental trial are presented herein. According to the diffraction pattern of the FeMoCrNiBaHf advanced alloy sample, the peak bandwidth indicated a fine-grained and ultimately homogeneous solid network. In fact, the formation of a nano-crystalline structure and high lattice strain were the main factors of peak flattening, and the increase in lattice strain was due to the different atomic sizes of the intergranular components (Figure 1). 


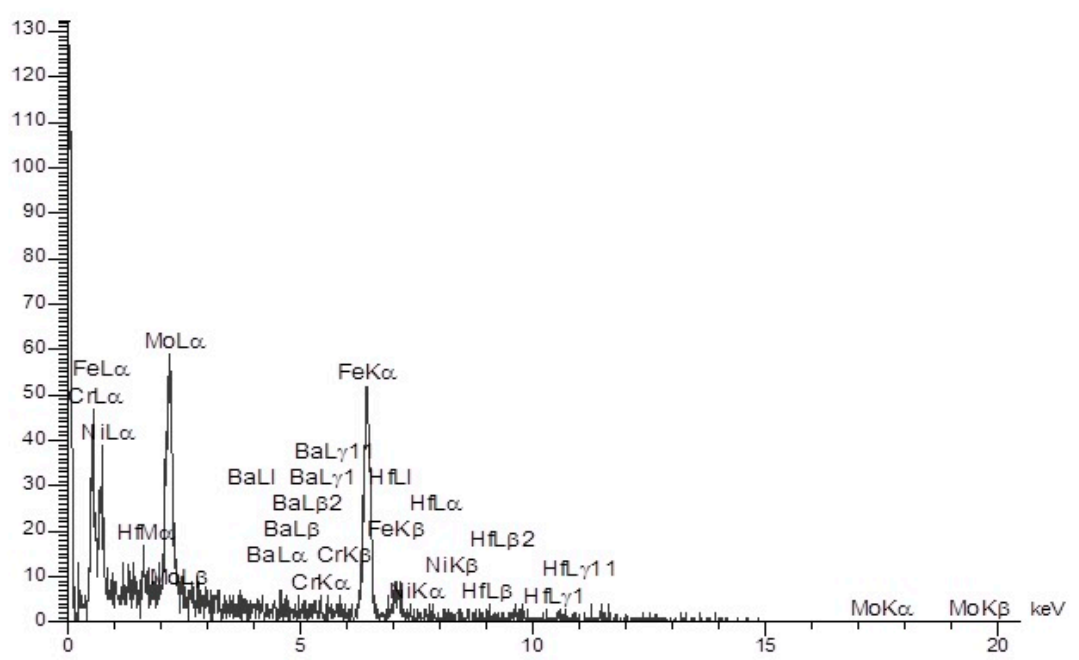

Figure 1. X-ray diffraction of high-entropy nano-alloy samples.

The morphology of the high-entropy FeMoCrNiBaHf nano-alloy magnified by a Fe-SEM (Field Emission Scanning Electron Microscopes) instrument (Fe-SEM-MIRA3, TESCAN-XMU) is shown in Figure 2. The smaller particles tended to boil and produce larger particles, while the larger particles themselves became smaller particles during the manufacturing process; consequently, the particle size distribution was very small. As can be seen, the particle dimensions were less than $100 \mathrm{~nm}$ (Figure 2).
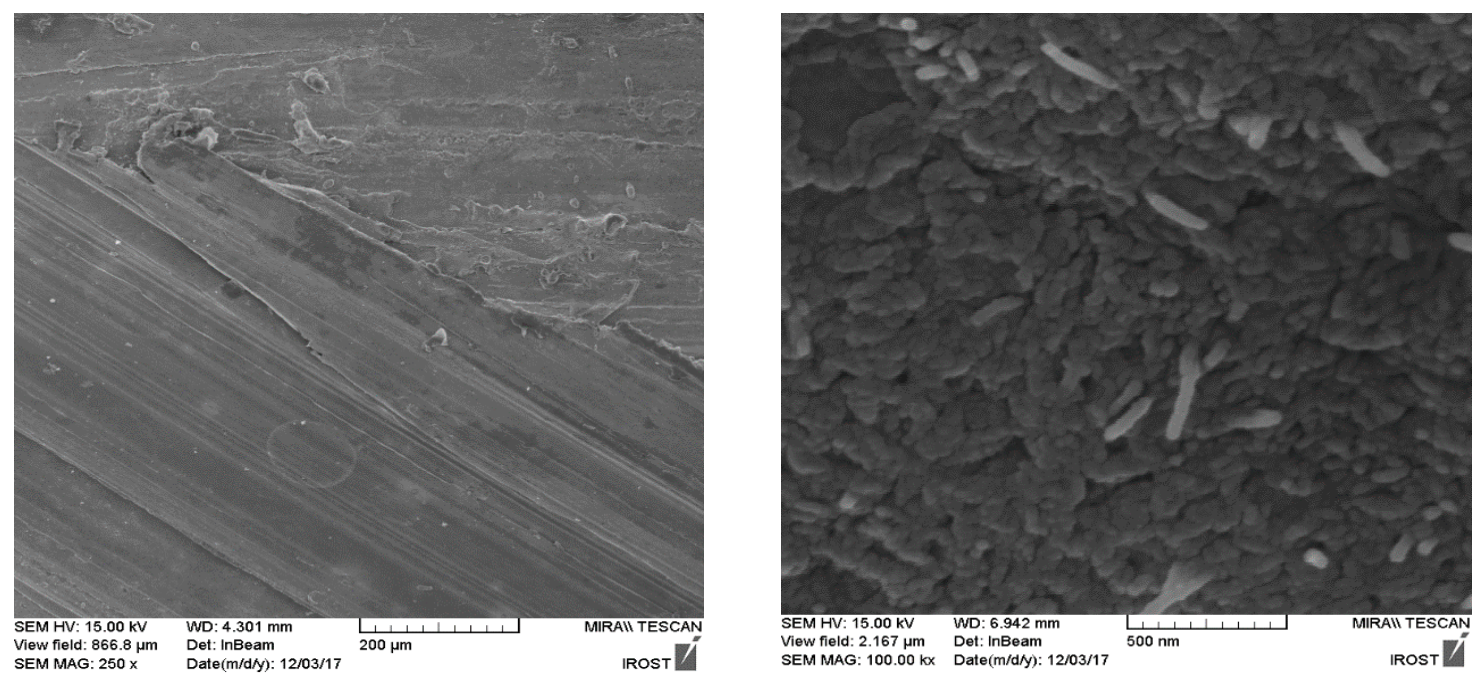

Figure 2. FE-SEM microscopy image of high-entropy nano-alloy, with dimensions less than $100 \mathrm{~nm}$ (current $298 \mu \mathrm{A}$; voltage $15.0 \mathrm{kV}$ ).

\subsection{Preparation of Mineral Sample for the High-Entropy Alloy Wear Test}

Iron ore (hematite) with $94 \% \mathrm{Fe}_{2} \mathrm{O}_{3}$ from Afghanistan (Figure 3a) and copper oxide (malachite and azurite) samples were selected (Figure $3 \mathrm{~b}$ ) for use in this investigation. These specimens, which were required to be completely dry, consisted of $1.6 \mathrm{~kg}$ with particle sizes of $-0.019+0.0125 \mathrm{~m}\left(-\frac{3}{4}+\frac{1}{2} \mathrm{in}\right)$, which were obtained by crushing larger particles and sorting using a screen. Usually, the initial value required for this experiment consisted of taking $5 \mathrm{~kg}$ of ore with a particle range of $-0.019+0.0125 \mathrm{~m}$. The results of the XRF analysis are listed in Table 2. 


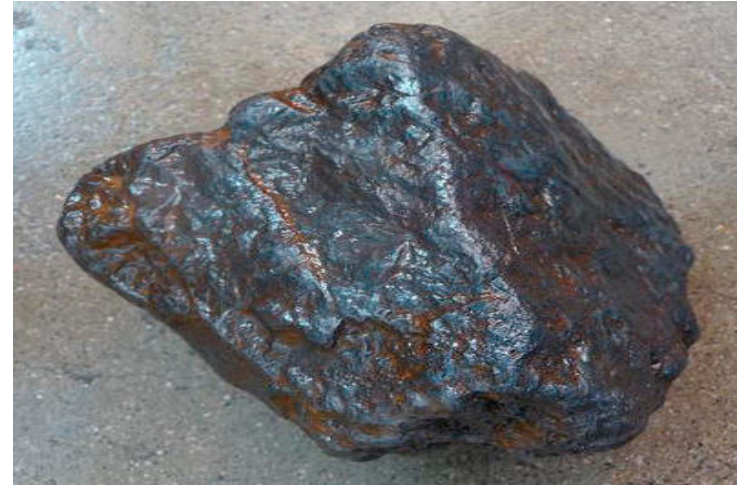

(a)

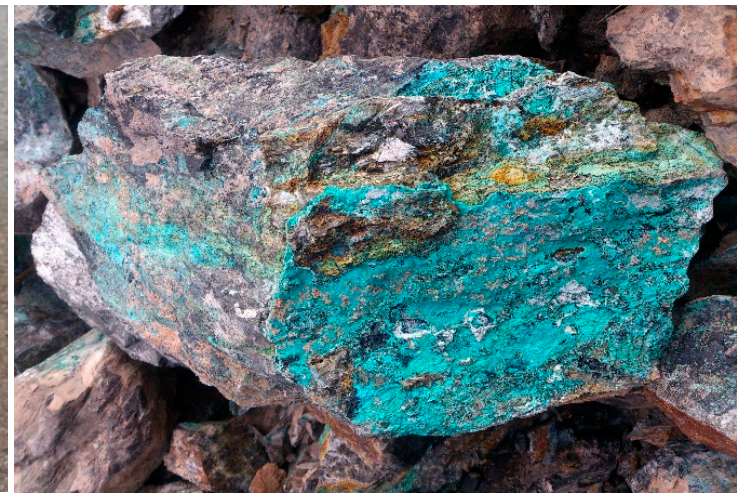

(b)

Figure 3. (a) Hematite iron ore sample from Afghanistan. (b) Copper oxide ore sample from Iran.

Table 2. XRF test results for titration of iron and copper oxide samples.

\begin{tabular}{ccccccccccc}
\hline Ore & \multicolumn{10}{c}{ Element (\%) } \\
\hline \multirow{2}{*}{ Copper Ore } & $\mathrm{Cu}$ & $\mathrm{TiO}_{2}$ & $\mathrm{SO}_{3}$ & $\mathrm{MnO}$ & $\mathrm{MgO}$ & $\mathrm{Fe}$ & $\mathrm{CaO}$ & $\mathrm{Al}_{2} \mathrm{O}_{3}$ & $\mathrm{SiO}_{2}$ & $\mathrm{LOI}$ \\
& 4.88 & 1.32 & 0.25 & 0.82 & 2.4 & 22.88 & 27.93 & 7.72 & 29.44 & 2.36 \\
\hline \multirow{2}{*}{ Iron Ore } & $\mathrm{Fe}_{2} \mathrm{O}_{3}$ & $\mathrm{TiO}_{2}$ & $\mathrm{SO}_{3}$ & $\mathrm{MnO}$ & $\mathrm{MgO}$ & $\mathrm{K}_{2} \mathrm{O}$ & $\mathrm{CaO}$ & $\mathrm{Al}_{2} \mathrm{O}_{3}$ & $\mathrm{SiO}_{2}$ & $\mathrm{LOI}$ \\
& 93.96 & - & 0.33 & - & - & 0.12 & 0.62 & 0.83 & 1.77 & 2.37 \\
\hline
\end{tabular}

\subsection{Preparation and Testing of Mineral Abrasion Measurement Using Blades Coated with High-Entropy} FeMoCrNiBaHf Nano-Alloy

Typically, the device consisted of $0.076 \mathrm{~m} \times 0.013 \mathrm{~m}$ blades of a metal substrate and a base of hard alloy steel, which included some nickel and molybdenum (500 Brinell 51 Rockwell). In this project, we tested the wear index once with a standard blade, and then again with the blade covered with high-entropy FeMoCrNiBaHf nano-alloy to a depth of $0.004 \mathrm{~m}$. The test sample was obtained from Nano Mine Tech Co. The dimensions of both blades were selected using the same test. The blade was attached to a shaft that rotated at a speed of $624 \mathrm{rpm}$. The rotor was in the center of a cylinder, $0.305 \mathrm{~m}$ in diameter and $0.114 \mathrm{~m}$ high. The cylinder also rotated in the direction of the blade at a speed of 51 rpm (Figure 4).

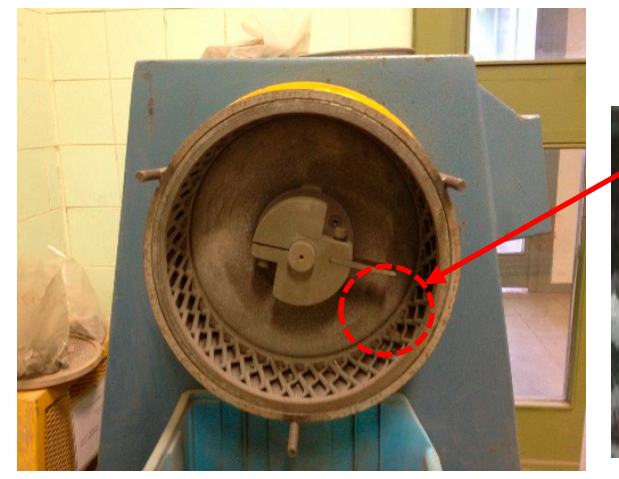

(a)

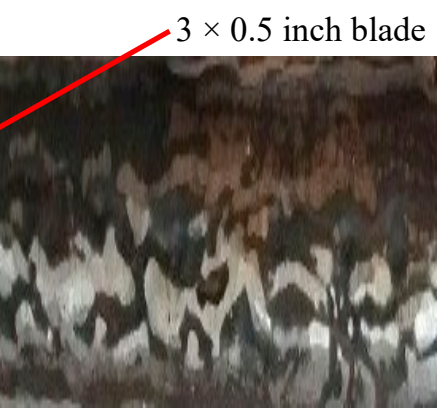

(b)

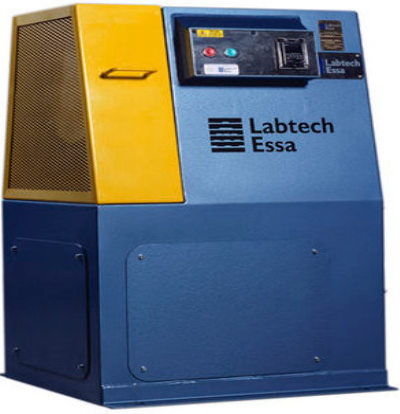

(c)

Figure 4. Mineral wear test of the band index, rotor, and mineral chamber (a); a blade coated with the high-entropy nano-alloy (b); full view of the mineral abrasive band index (Labtech Essa) (c).

This test did not require any special working conditions and was performed at ambient pressure and temperature to determine the mineral wear index of the equipment for mineral processing. 
Wear studies were conducted using laboratory and pilot scale industrial samples according to the ASTM-G65 standard by exposing the metallic materials to scratching abrasions via the dry sand/rubber wheel test. The abrasive used was $100 \%$ silica $\left(\mathrm{SiO}_{2}\right)$. The test conditions for the equipment included a wheel diameter of $235 \mathrm{~mm}$, a sand flow of $320 \mathrm{~g} / \mathrm{min}$, a test load of $130 \mathrm{rpm}$, a wheel width of $12.7 \mathrm{~mm}$, a wheel speed of 5610 revolutions/min, and a wheel hardness of Durometer A-60. The results of the abrasion test were reported as volume loss per cubic millimeter.

\subsection{Measurement Procedure, Repeatability, and Reproducibility of Reduced Metal by Bond Abrasion Index}

As shown by the tests for the first day and second day structures in Table 3 , the mean weight loss due to abrasion was measured for 10 standard alloy steel blade samples and 10 alloy steel blades covered with N-HEA samples. Three measurements for each test (A and B) for samples 1-10 were performed; the total mean for the standard alloy steel blade was $0.0803 \times 10^{-3} \mathrm{~kg}$ and the total mean for the alloy steel blade covered by N-HEA was $0.0908 \times 10^{-3} \mathrm{~kg}$. The standard deviation, repeatability, and reproducibility values based on $95 \%$ confidence levels were performed for the alloy steel blade covered by N-HEA, yielding figures of 0.00016, 0.00047, and 0.00040, and 0.0003, 0.00047, and 0.00042 for the standard alloy steel blade. The experimental data for each of the alloys were fitted and examined by calculation of the correlation coefficient $\left(R^{2}\right)$. It was found that the alloy steel blade covered by N-HEA had an $R^{2}$ of 0.9423 and the standard alloy steel blade had an $R^{2}$ of 0.9552 , which were both close to 1.0 . 
Table 3. The mean weight loss $(\mathrm{kg})$ due to Bond abrasion process.

\begin{tabular}{|c|c|c|c|c|c|c|c|c|c|c|c|}
\hline \multicolumn{6}{|c|}{ First Day (A) } & \multicolumn{6}{|c|}{ Second Day (B) } \\
\hline \multicolumn{6}{|c|}{$\begin{array}{c}\text { Abrasion Rate (AR) of Alloy Steel Blade Covered } \\
\text { by N-HEA for Copper Ore }\end{array}$} & \multicolumn{6}{|c|}{$\begin{array}{l}\text { Abrasion Rate (AR) of Alloy Steel Blade Covered } \\
\text { by N-HEA for Iron Ore }\end{array}$} \\
\hline$x$ & $n=30$ & $\bar{x}, n=10$ & $d$ & $S_{\bar{x}}$ & $\bar{X}$ & $x$ & $n=30$ & $\bar{x}, n=10$ & $d$ & $S_{\bar{x}}$ & $\bar{X}$ \\
\hline $\begin{array}{l}1 \\
2 \\
3\end{array}$ & $\begin{array}{l}0.0793 \times 10^{-3} \\
0.0803 \times 10^{-3} \\
0.0801 \times 10^{-3}\end{array}$ & $0.0799 \times 10^{-3}$ & $-0.4 \times 10^{-3}$ & $0.52915 \times 10^{-3}$ & & $\begin{array}{l}1 \\
2 \\
3\end{array}$ & $\begin{array}{l}0.0903 \times 10^{-3} \\
0.0905 \times 10^{-3} \\
0.0907 \times 10^{-3}\end{array}$ & $0.0905 \times 10^{-3}$ & $-0.2 \times 10^{-3}$ & $0.2 \times 10^{-3}$ & \\
\hline $\begin{array}{l}4 \\
5 \\
6\end{array}$ & $\begin{array}{l}0.0801 \times 10^{-3} \\
0.0802 \times 10^{-3} \\
0.0798 \times 10^{-3}\end{array}$ & $0.0800 \times 10^{-3}$ & $-0.3 \times 10^{-3}$ & 0. $20817 \times 10^{-3}$ & & $\begin{array}{l}4 \\
5 \\
6\end{array}$ & $\begin{array}{l}0.0905 \times 10^{-3} \\
0.0905 \times 10^{-3} \\
0.0907 \times 10^{-3}\end{array}$ & $0.0906 \times 10^{-3}$ & $-0.2 \times 10^{-3}$ & $0.11547 \times 10^{-3}$ & \\
\hline $\begin{array}{l}7 \\
8 \\
9\end{array}$ & $\begin{array}{l}0.0805 \times 10^{-3} \\
0.0800 \times 10^{-3} \\
0.0798 \times 10^{-3}\end{array}$ & $0.0801 \times 10^{-3}$ & $-0.2 \times 10^{-3}$ & $0.36055 \times 10^{-3}$ & & $\begin{array}{l}7 \\
8 \\
9\end{array}$ & $\begin{array}{l}0.0905 \times 10^{-3} \\
0.0908 \times 10^{-3} \\
0.0912 \times 10^{-3}\end{array}$ & $0.0908 \times 10^{-3}$ & $0.1 \times 10^{-3}$ & $0.35119 \times 10^{-3}$ & \\
\hline $\begin{array}{l}10 \\
11 \\
12\end{array}$ & $\begin{array}{l}0.0799 \times 10^{-3} \\
0.0804 \times 10^{-3} \\
0.0808 \times 10^{-3}\end{array}$ & $0.0804 \times 10^{-3}$ & $0.0 \times 10^{-3}$ & 0. $45092 \times 10^{-3}$ & & $\begin{array}{l}10 \\
11 \\
12\end{array}$ & $\begin{array}{l}0.0907 \times 10^{-3} \\
0.0908 \times 10^{-3} \\
0.0911 \times 10^{-3}\end{array}$ & $0.0909 \times 10^{-3}$ & $0.1 \times 10^{-3}$ & $0.20817 \times 10^{-3}$ & \\
\hline $\begin{array}{l}13 \\
14 \\
15\end{array}$ & $\begin{array}{l}0.0798 \times 10^{-3} \\
0.0812 \times 10^{-3} \\
0.0807 \times 10^{-3}\end{array}$ & $0.0806 \times 10^{-3}$ & $0.2 \times 10^{-3}$ & 0. $70946 \times 10^{-3}$ & & $\begin{array}{l}13 \\
14 \\
15\end{array}$ & $\begin{array}{l}0.0909 \times 10^{-3} \\
0.0910 \times 10^{-3} \\
0.0911 \times 10^{-3}\end{array}$ & $0.0910 \times 10^{-3}$ & $0.3 \times 10^{-3}$ & $0.1 \times 10^{-3}$ & \\
\hline $\begin{array}{l}16 \\
17 \\
18\end{array}$ & $\begin{array}{l}0.0797 \times 10^{-3} \\
0.0808 \times 10^{-3} \\
0.0801 \times 10^{-3}\end{array}$ & $0.0802 \times 10^{-3}$ & $-0.1 \times 10^{-3}$ & $0.55677 \times 10^{-3}$ & $\times 10^{-}$ & $\begin{array}{l}16 \\
17 \\
18\end{array}$ & $\begin{array}{l}0.0904 \times 10^{-3} \\
0.0906 \times 10^{-3} \\
0.0907 \times 10^{-3}\end{array}$ & $0.0906 \times 10^{-3}$ & $-0.2 \times 10^{-3}$ & $0.15275 \times 10^{-3}$ & $0.0908 \times 10^{-3}$ \\
\hline $\begin{array}{l}19 \\
20 \\
21\end{array}$ & $\begin{array}{l}0.0803 \times 10^{-3} \\
0.0806 \times 10^{-3} \\
0.0799 \times 10^{-3}\end{array}$ & $0.0803 \times 10^{-3}$ & $-0.1 \times 10^{-3}$ & $0.35119 \times 10^{-3}$ & & $\begin{array}{l}19 \\
20 \\
21\end{array}$ & $\begin{array}{l}0.0907 \times 10^{-3} \\
0.0907 \times 10^{-3} \\
0.0908 \times 10^{-3}\end{array}$ & $0.0907 \times 10^{-3}$ & $0.0 \times 10^{-3}$ & $5.7735 \times 10^{-5}$ & \\
\hline $\begin{array}{l}22 \\
23 \\
24\end{array}$ & $\begin{array}{l}0.0805 \times 10^{-3} \\
0.0807 \times 10^{-3} \\
0.0800 \times 10^{-3}\end{array}$ & $0.0804 \times 10^{-3}$ & $0.1 \times 10^{-3}$ & $0.36056 \times 10^{-3}$ & & $\begin{array}{l}22 \\
23 \\
24\end{array}$ & $\begin{array}{l}0.0906 \times 10^{-3} \\
0.0907 \times 10^{-3} \\
0.0909 \times 10^{-3}\end{array}$ & $0.0907 \times 10^{-3}$ & $0.0 \times 10^{-3}$ & $0.15275 \times 10^{-3}$ & \\
\hline $\begin{array}{l}25 \\
26 \\
27\end{array}$ & $\begin{array}{l}0.0804 \times 10^{-3} \\
0.0807 \times 10^{-3} \\
0.0810 \times 10^{-3}\end{array}$ & $0.0807 \times 10^{-3}$ & $0.4 \times 10^{-3}$ & $0.3 \times 10^{-3}$ & & $\begin{array}{l}25 \\
26 \\
27\end{array}$ & $\begin{array}{c}0.0907 \times 10^{-3} \\
0.0908 \times 10^{-3} \\
0.091 \times 10^{-3}\end{array}$ & $0.0908 \times 10^{-3}$ & $0.1 \times 10^{-3}$ & $0.15275 \times 10^{-3}$ & \\
\hline $\begin{array}{l}28 \\
29 \\
30\end{array}$ & $\begin{array}{l}0.0805 \times 10^{-3} \\
0.0811 \times 10^{-3} \\
0.0808 \times 10^{-3}\end{array}$ & $0.0808 \times 10^{-3}$ & $0.5 \times 10^{-3}$ & $0.3 \times 10^{-3}$ & & $\begin{array}{l}28 \\
29 \\
30\end{array}$ & $\begin{array}{l}0.0908 \times 10^{-3} \\
0.0909 \times 10^{-3} \\
0.0910 \times 10^{-3}\end{array}$ & $0.0909 \times 10^{-3}$ & $0.1 \times 10^{-3}$ & $1 \times 10^{-4}$ & \\
\hline
\end{tabular}




\section{Results}

We first divided the $1.6 \mathrm{~kg}$ sample from each ore into four $0.4 \mathrm{~kg}$ samples with a separator to measure wear resistance. This test was used to check the wear resistance of hard coatings. Both standard blades and blades coated with high-entropy nano-alloy were weighed with a precision of $1 \times 10^{-7} \mathrm{~kg}$ using balancing. The blade was inserted into the rotor and secured by a clamp. The first sample $(0.4 \mathrm{~kg})$ was poured into the apparatus and sealed. The machine was turned on for 900 seconds using an automatic timer. This was repeated for all four samples of iron ore and copper ore and the product was kept separately for each step. The blade was then removed from the enclosure and thoroughly cleaned and dried with alcohol and acetone. Then it was weighed again. Screening for the test materials was performed in four steps up to about $0.000075 \mathrm{~m}$. The amount of wear was measured, weighed, and expressed in standard units, as shown in the corresponding tables. The calculated values of the wear rate and index are displayed in Table 4. As can be seen, using the high-entropy alloy sample, the amount of metal was reduced significantly by pounds per kilowatt per hour of energy consumed.

Table 4. Calculated rates and wear indexes for both blades and the copper and iron ore samples.

\begin{tabular}{|c|c|c|c|c|c|}
\hline \multirow{2}{*}{\multicolumn{4}{|c|}{ The Bond Abrasion Index $\left(A_{i}\right)$ and Abrasion Rate (AR) }} & \multicolumn{2}{|c|}{ Ore Type } \\
\hline & & & & Iron Ore & Copper Ore \\
\hline \multicolumn{4}{|c|}{$\begin{array}{l}\text { Standard alloy steel blade, } \mathrm{A}_{\mathrm{i}}(\mathrm{kg}) \\
\text { (hardness } 500 \text { Brinell } \sim 52 \text { Rockwell-HRC) }\end{array}$} & $0.1647 \times 10^{-3}$ & $0.1472 \times 10^{-3}$ \\
\hline \multicolumn{4}{|c|}{$\begin{array}{l}\text { Alloy steel blade covered by FeMoCrNiBaHf, } \mathrm{A}_{\mathrm{i}}(\mathrm{kg}) \\
\text { (hardness } 746 \text { Brinell } \sim 67 \text { Rockwell-HRC) }\end{array}$} & $0.0908 \times 10^{-3}$ & $0.0803 \times 10^{-3}$ \\
\hline \multirow{2}{*}{$\begin{array}{l}\text { Standard alloy } \\
\text { steel blade } \\
\text { Abrasion rate (AR) }\end{array}$} & $\begin{array}{l}\text { Dry ball mill } \\
(\mathrm{lb} / \mathrm{kWh})\end{array}$ & $\begin{array}{c}\text { Balls } \\
\text { Liners }\end{array}$ & $\begin{array}{c}0.05 \mathrm{Ai}^{0.5} \\
0.005 \mathrm{Ai}^{0.5}\end{array}$ & $\begin{array}{l}0.0203 \times 10^{-3} \\
0.0020 \times 10^{-3}\end{array}$ & $\begin{array}{l}0.0192 \times 10^{-3} \\
0.0019 \times 10^{-3}\end{array}$ \\
\hline & $\begin{array}{c}\text { Crushers (gyratory, } \\
\text { jaw, cone) } \\
(\mathrm{lb} / \mathrm{kWh})\end{array}$ & Liners & $(\mathrm{Ai}+0.22) / 11$ & $0.0350 \times 10^{-3}$ & $0.0334 \times 10^{-3}$ \\
\hline \multirow{2}{*}{$\begin{array}{l}\text { Alloy steel blade } \\
\text { covered by } \\
\text { Nano high-entropy } \\
\text { alloy } \\
\text { Abrasion rate (AR) }\end{array}$} & $\begin{array}{l}\text { Dry ball mill } \\
(\mathrm{lb} / \mathrm{kWh})\end{array}$ & $\begin{array}{c}\text { Balls } \\
\text { Liners }\end{array}$ & $\begin{array}{c}0.05 \mathrm{Ai}^{0.5} \\
0.005 \mathrm{Ai}^{0.5}\end{array}$ & $\begin{array}{c}0.0151 \times 10^{-3} \\
0.00151 \times 10^{-3}\end{array}$ & $\begin{array}{l}0.0142 \times 10^{-3} \\
0.0014 \times 10^{-3}\end{array}$ \\
\hline & $\begin{array}{c}\text { Crushers (gyratory, } \\
\text { jaw, cone) } \\
(\mathrm{lb} / \mathrm{kWh})\end{array}$ & Liners & $(\mathrm{Ai}+0.22) / 11$ & $0.0283 \times 10^{-3}$ & $0.0273 \times 10^{-3}$ \\
\hline
\end{tabular}

The hardness test results for the alloy sample were calculated as 67 Rockwell based on ASTM-G65 analysis. According to the abrasion rate parameters for the two samples of the hard alloy steel (including nickel and molybdenum) and the nano high-entropy alloy, the amount of alloy lost was reduced by $50 \%$. For instance, for the dry ball grinder and crusher (gyratory, jaw and cone) the rate of abrasion in the balls and liners was different for the standard alloy. However, the rate was decreased using a nano high-entropy alloy. Alloy use is not only important from an economical standpoint, but also shows a direct effect on the breakdown time of equipment for repair and maintenance. Reducing the amount of the alloy lost by half could have a great effect on the mining economy.

As can be seen from the SEM micrographs, the wear mechanisms for the metal matrix of the high-entropy nano-alloy were a mixture of impact, abrasion, and scratching wear (Figure 5). 


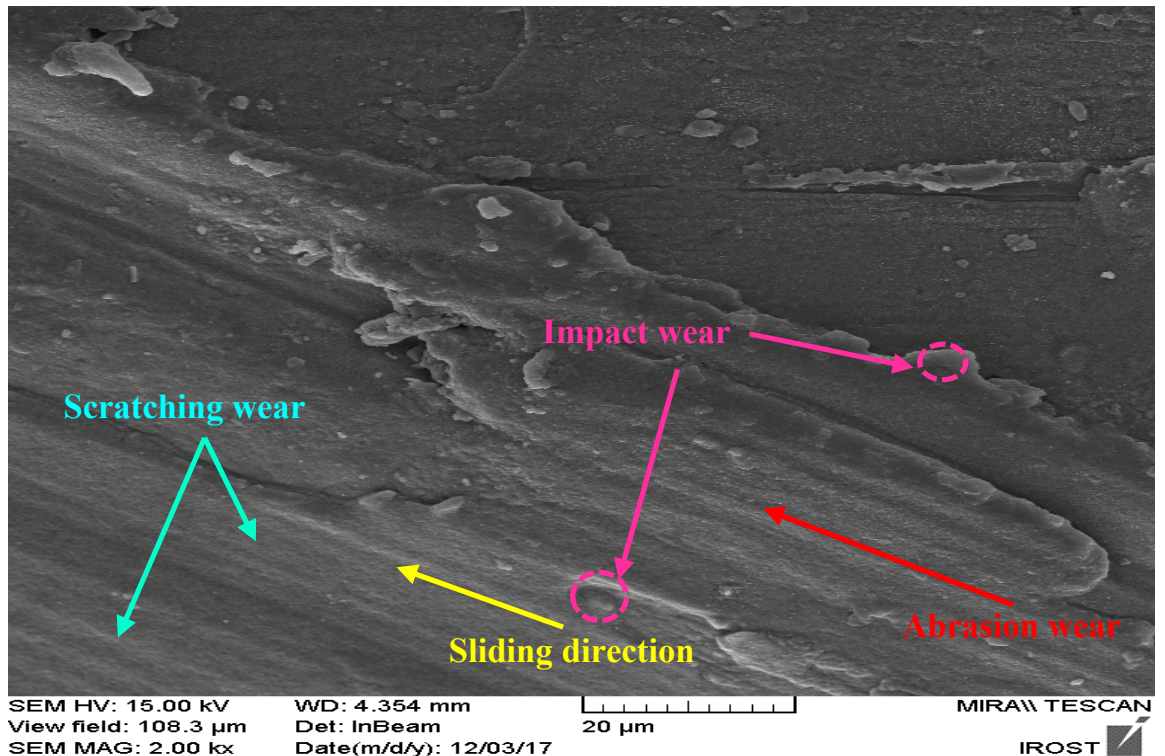

Figure 5. FE-SEM micrograph of wear of the metal matrix high-entropy nano-alloy, which were a combination of impact, abrasion, and scratching wear (current $298 \mu \mathrm{A}$; voltage $15.0 \mathrm{kV}$ ).

\section{Conclusions}

Evaluation of the wear effect of natural and inorganic iron and copper samples on a high-entropy nano-alloy and a parent alloy in wear tests showed different weight losses of the blade. The experimental wear causing loss of mass due to the use of the iron ore and copper rock ranged from $0.0001647 \mathrm{~kg}$ to $0.0000908 \mathrm{~kg}$ and from $0.0001472 \mathrm{~kg}$ to $0.0000803 \mathrm{~kg}$, respectively, for the uncovered and HEA covered materials. A substantial amount of hard-wearing coatings is required to meet the mining industry's annual needs. By creating a hard and accessible nano-coating, wear and tear of materials can be significantly reduced, which is both cost-effective and, with the application of this technical innovation, could save energy. The use of high-entropy alloys in heavy industries is a new innovational option to allow producers to gain a competitive advantage in the market place.

Author Contributions: Supervision, M.K. and H.P.; writing—original draft, M.H. All authors have read and agreed to the published version of the manuscript.

Funding: This research received no external funding.

Acknowledgments: The authors appreciate the sincere cooperation and support of the faculty of Mining, Petroleum, and Geophysics department of the Shahrood University of Technology, Iran; School of Chemical and Metallurgical Engineering, University of the Witwatersrand, Johannesburg, South Africa; Department of Natural Science, Faculty of Science and Engineering, Manchester Metropolitan University, Manchester, UK; Faculty of Metallurgy and Materials Engineering, University of Tehran, Iran; and also, Nano Mine Tech Co. to accomplish the research.

Conflicts of Interest: The authors declare no conflict of interest.

\section{References}

1. Jeswiet, J.; Szekeres, A. Energy Consumption in Mining Comminution. Procedia CIRP 2016, 48, 140-145. [CrossRef]

2. Fang, Z.Z.; Chandran, R.; Koopman, M. A New Method for Low Cost Production of Titanium Alloys for Reducing Energy Consumption of Mechanical Systems. Ph.D. Thesis, The University of Utah, Salt Lake City, UT, USA, 2016. [CrossRef]

3. Murty, B.S.; Yeh, J.; Ranganathan, S. Ranganathan, High-entropy Alloys, 1st ed.; Butterworth-Heinemann: Oxford, UK, 2019; ISBN 9780128002513.

4. Bhushan, R.K. Optimization of cutting parameters for minimizing power consumption and maximizing tool life during machining of $\mathrm{Al}$ alloy SiC particle composites. J. Clean. Prod. 2013, 39, 242-254. [CrossRef] 
5. Dube, N.B.; Hutchings, I.M. Influence of particle fracture in the high-stress and low-stress abrasive wear of steel. Wear 1999, 233, 246-256. [CrossRef]

6. Misra, A.; Finnie, I. A classification of three-body abrasive wear and design of a new tester. Wear 1980, 60, 111-121. [CrossRef]

7. Chacon-Nava, J.G.; Martinez-Villafañe, A.; Almeraya-Calderon, F.; Cabral-Miramontes, J.A.; Stack, M.M. Some remarks on particle size effects on the abrasion of a range of Fe based alloys. Tribol. Int. 2009, 43, 1307-1317. [CrossRef]

8. Wirojanupatump, S.; Shipway, P.H. Abrasion of mild steel in wet and dry conditions with the rubber and steel wheel abrasion apparatus. Wear 2000, 239, 91-101. [CrossRef]

9. Ala-Kleme, S.; Livimatainen, J.; Hellman, J.; Hannula, S.P. Abrasive wear properties of tool steel matrix composites in rubber wheel abrasion test and laboratory cone crusher experiments. Wear 2007, 263, 180-187. [CrossRef]

10. Nahvi, S.M.; Shipway, P.H.; McCartney, D.G. Particle motion and modes of wear in the dry sand-rubber wheel abrasion test. Wear 2009, 267, 2083-2091. [CrossRef]

11. Stevenson, A.N.J.; Hutchings, I.M. Development of the dry sand/rubber wheel abrasion test. Wear 1996, 195, 232-240. [CrossRef]

12. G65-04 Standard Test Method for Measuring Abrasion Resistance Using the Dry Sand/Rubber Wheel Apparatus. In Book of Standards 03.02; ASTM International: Montgomery County, PA, USA, 2006; pp. 245-256.

13. Davis, J.R. Davis and Associates, Hardfacing, Weld Cladding, and Dissimilar Metal Joining. In Metals Handbook, 10th ed.; American Society for Metals: Russell, OH, USA, 1997; Volume 6, pp. 789-829.

14. Kokabi, A.H. Welding Technology, 5th ed.; Azadeh Publication: Tehran, Iran, 2003; ISBN 978-964-7982-43-6.

15. Welding Handbook, Surfacing, 6th ed.; American Welding Society: Miami, FL, USA, 1970; Volume 3.

16. Bialobrzeska, B.; Kostencki, P. Abrasive wear characteristics of selected low-alloy boron steels as measured in both field experiments and laboratory tests. Wear 2015, 328, 149-159. [CrossRef]

17. Gregory, E.N.; Bartle, M. Weld Surfacing and Harfacing. In Materials for Harfacing; The Welding Institute: Cambridge, MA, USA, 1980; pp. 11-21.

18. Zhang, K.B.; Fu, Z.Y.; Zhang, J.Y.; Wang, W.M.; Wang, H.; Wang, Y.C.; Zhanga, Q.J.; Shi, J. Microstructure and mechanical properties of CoCrFeNiTiAlx high-entropy alloys. Mater. Sci. Eng. A 2009, 508, 214-219. [CrossRef]

19. Tsau, C.-H.; Wang, W.-L. Microstructures, Hardness and Corrosion Behaviors of FeCoNiNb ${ }_{0.5} \mathrm{Mo}_{0.5}$ and FeCoNiNb High-Entropy Alloys. Materials 2018, 11, 16. [CrossRef]

20. Wang, Y.P.; Li, B.S.; Ren, M.X.; Yang, C.; Fu, H.Z. Microstructure and compressive properties of $\mathrm{AlCrFeCoNi}$ high-entropy alloy. Mater. Sci. Eng. A 2008, 491, 154-158. [CrossRef]

21. Zhu, J.M.; Fu, H.M.; Zhang, H.F.; Wang, A.M.; Li, H.; Hua, Z.Q. Microstructures and compressive properties of multicomponent AlCoCrFeNiMox alloys. Mater. Sci. Eng. A 2010, 527, 6975-6979. [CrossRef]

22. Chuang, M.-H.; Tsai, M.-H.; Wang, W.-R.; Lin, S.-J.; Yeh, J.-W. Microstructure and wear behavior of $\mathrm{Al}_{\mathrm{x}} \mathrm{Co}_{1.5} \mathrm{CrFeNi}_{1.5} \mathrm{Ti}_{\mathrm{y}}$ high-entropy alloys. Acta Mater. 2011, 59, 6308-6317.

23. Yeh, J.W.; Chen, S.K.; Lin, S.J.; Gan, J.Y.; Chin, T.S.; Shun, T.T.; Tsau, C.H.; Chang, S.Y. Nanostructured high-entropy alloys with multiple principal elements: Novel alloy design concepts and outcomes. Adv. Eng. Mater. 2004, 6, 299-303. [CrossRef]

24. Youssef, K.M.; Zaddach, A.J.; Niu, C.; Irving, D.L.; Koch, C.C. A Novel Low-Density, High-Hardness, High-Entropy Alloy with Close-Packed Single-Phase Nanocrystalline Structures. Mater. Res. Lett. 2015, 3, 95-99. [CrossRef]

25. Raabe, D.; Tasan, C.C.; Springer, H.; Bausch, M. From High-Entropy Alloys to High-Entropy Steels. Steel Res. Int. 2015, 86, 1127-1138. [CrossRef]

26. SBIR/STTR. 2018; Exploration of High-Entropy Alloys for Turbine Applications|SBIR.Gov. Available online: https://www.sbir.gov/sbirsearch/detail/1212591 (accessed on 10 April 2018).

27. Gludovatz, B.; Hohenwarter, A.; Catoor, D.; Chang, E.H.; George, E.P.; Ritchie, R.O. A Fracture-Resistant High-Entropy Alloy for Cryogenic Applications. Science 2014, 345, 1153-1158. [CrossRef]

28. Ames Laboratory. n.d. Development of Radically Enhanced Alnico Magnets (DREAM) for Traction Drive Motors. Available online: https://www.ameslab.gov/dmse/fwp/development-radically-enhanced-alnicomagnets-dream-traction-drive-motors (accessed on 9 April 2015). 
29. Saal, J. Exploration of High-Entropy Alloys for Turbine Applications. 2016. Available online: https://www.netl. doe.gov/FileLibrary/Events/2016/utsr/Wednesday/James-Saal.pdf (accessed on 2 November 2016).

30. Dima, A.; Bhaskarla, S.; Becker, C.; Brady, M.; Campbell, C.; Dessauw, P.; Hanisch, R.; Kattner, U.; Kroenlein, K.; Newrock, M.; et al. Informatics Infrastructure for the Materials Genome Initiative. JOM 2016, 68, 2053-2064. [CrossRef]

31. Li, D.; Zhang, Y. The Ultrahigh Charpy Impact Toughness of Forged AlxCoCrFeNi High-entropy Alloys at Room and Cryogenic Temperatures. Intermetallics 2016, 70, 24-28. [CrossRef]

32. Löbel, M.; Lindner, T.; Mehner, T.; Lampke, T. Microstructure and Wear Resistance of AlCoCrFeNiTi High-Entropy Alloy Coatings Produced by HVOF. Coatings 2017, 7, 144. [CrossRef]

33. Gao, M. Development of New High-entropy Alloys for Brazing of Ni-Base Superalloys. Colorado School of Mines. 2017. Available online: https://hdl.handle.net/11124/171240890837 (accessed on 10 April 2018).

34. Feng, R.; Gao, M.; Lee, C.; Mathes, M.; Zuo, T.; Chen, S.; Hawk, J.; Zhang, Y.; Liaw, P. Design of Light-Weight High-Entropy Alloys. Entropy 2016, 18, 333. [CrossRef]

35. Kumar, A.; Gupta, M. An Insight into Evolution of Light Weight High-entropy Alloys: A Review. Metals 2016, 6, 199. [CrossRef]

36. Feng, R.; Gao, M.C.; Zhang, C.; Guo, W.; Poplawsky, J.D.; Zhang, F.; Hawk, J.A.; Neuefeind, J.C.; Ren, Y.; Liaw, P.K. Phase Stability and Transformation in a Light-Weight High-Entropy Alloy. Acta Mater. 2018, 146, 280-293. [CrossRef]

37. Yao, C.; Zhang, P.; Liu, M.; Li, G.; Ye, J.; Liu, P.; Tong, Y. Electrochemical Preparation and Magnetic Study of Bi-Fe-Co-Ni-Mn High-entropy Alloy. Electrochim. Acta 2008, 53, 8359-8365. [CrossRef]

38. Zhu, J.M.; Fu, H.M.; Zhang, H.F.; Wang, A.M.; Li, H.; Hu, Z.Q. Microstructure and compressive properties of multiprincipal component AlCoCrFeNiC $x$ alloys. J. Alloys Compd. 2011, 509, 3476-3480. [CrossRef]

39. Wang, X.F.; Zhang, Y.; Qiao, Y.; Chen, G.L. Novel microstructure and properties of multicomponent CoCrCuFeNiTi ${ }_{x}$ alloys. Intermetallics 2007, 15, 357-362. [CrossRef]

40. Ma, S.G.; Zhang, Y. Effect of $\mathrm{Nb}$ addition on the microstructure and properties of AlCoCrFeNi high-entropy alloy, Mater. Sci. Eng. A 2012, 532, 480-486. [CrossRef]

41. Hsu, C.Y.; Sheu, T.S.; Yeh, J.W.; Chen, S.K. Effect of iron content on wear behavior of $\mathrm{AlCoCrFexMo}_{0.5} \mathrm{Ni}$ high-entropy alloys. Wear 2010, 268, 653-659. [CrossRef]

42. Hsu, C.-Y.; Wang, W.-R.; Tang, W.-Y.; Chen, S.-K.; Yeh, J.-W. Microstructure and mechanical properties of new AlCoxCrFe-Mo ${ }_{0.5} \mathrm{Ni}$ high-entropy alloys. Adv. Eng. Mater. 2010, 12, 44-49. [CrossRef]

43. Senkov, N.O.; Isheim, D.; Seidman, D.N.; Pilchak, A.L. Development of a Refractory High-entropy Superalloy. Entropy 2016, 18, 102. [CrossRef]

44. Senkov, N.O.; Wilks, G.B.; Scott, J.M.; Miracle, D.B. Mechanical Properties of $\mathrm{Nb}_{25} \mathrm{Mo}_{25} \mathrm{Ta}_{25} \mathrm{~W}_{25}$ and $\mathrm{V}_{20} \mathrm{Nb}_{20} \mathrm{Mo}_{20} \mathrm{Ta}_{20} \mathrm{~W}_{20}$ Refractory High-entropy Alloys. Intermetallics 2011, 19, 698-706. [CrossRef]

45. Chen, W.; Fu, Z.; Fang, S.; Xiao, H.; Zhu, D. Alloying behavior, microstructure and mechanical properties in a $\mathrm{FeNiCrCo}_{0.3} \mathrm{Al}_{0.7}$ high-entropy alloy. Mater. Des. 2013, 51, 854-860. [CrossRef]

46. Li, C.; Li, J.C.; Zhao, M.; Jiang, Q. Effect of alloying elements on microstructure and properties of multiprincipal elements high-entropy alloys. J. Alloys Compd. 2009, 475, 752-757. [CrossRef]

47. Senkov, N.O.; Scott, J.M.; Senkova, S.V.; Meisenkothen, F.; Miracle, D.B.; Woodward, C.F. Microstructure and Elevated Temperature Properties of a Refractory TaNbHfZrTi Alloy. J. Mater. Sci. 2012, 47, 4062-4074. [CrossRef]

48. Miracle, B.D.; Senkov, O.N. A Critical Review of High-entropy Alloys and Related Concepts. Acta Mater. 2017, 122, 448-511. [CrossRef]

49. Bridges, D.; Zhang, S.; Lang, S.; Gao, M.; Yu, Z.; Feng, Z.; Hu, A. Laser Brazing of a Nickel-Based Superalloy Using a Ni-Mn-Fe-Co-Cu High-entropy Alloy Filler Metal. Mater. Lett. 2018, 215, 11-14. [CrossRef]

50. SBIR/STTR. 2018; Advanced Bond Coats for Thermal Barrier Coating Systems Based on High-entropy Alloys|SBIR.Gov. Available online: https://www.sbir.gov/sbirsearch/detail/890837 (accessed on 10 April 2018).

51. Zhu, J.M.; Fu, H.M.; Zhang, H.F.; Wang, A.M.; Li, H.; Hu, Z.Q. Synthesis and properties of multiprincipal component AlCoCr-FeNiSi $x_{x}$ alloys. Mater. Sci. Eng. A 2010, 527, 7210-7214. [CrossRef]

52. Nurthen, P.; Bergman, O. IHauer: Carbide Design in Wear Resistant Powder Materials; PM2008 World Congress: Washington, DC, USA, 2008.

53. Li, Z.; Zhao, S.; Diao, H.; Liaw, P.K.; Meyers, M.A. High-Velocity Deformation of $\mathrm{Al}_{0.3} \mathrm{CoCrFeNi}$ High-Entropy Alloy: Remarkable Resistance to Shear Failure. Sci. Rep. 2017, 7, 42742. [CrossRef] 
54. Nair, B.R.; Arora, H.S.; Mukherjee, S.; Singh, S.; Singh, H.; Grewal, H.S. Exceptionally High Cavitation Erosion and Corrosion Resistance of a High-entropy Alloy. Ultrason. Sonochem. 2018, 41, 252-260. [CrossRef] [PubMed]

55. Zhang, K.B.; Fu, Z.Y.; Zhang, J.Y.; Wang, W.M.; Lee, S.W.; Niihara, K. Characterization of nanocrystal line CoCrFeNiTiAl high-entropy solid solution processed by mechanical alloying. J. Alloys Compd. 2010, 495, 33-38. [CrossRef]

56. Zhang, K.B.; Fu, Z.Y.; Zhang, J.Y.; Shi, J.; Wang, W.M.; Wang, H.; Wang, Y.C.; Zhang, Q.J. Nanocrystalline $\mathrm{CoCrFeNiCuAl}$ high-entropy solid solution synthesized by mechanical alloying. J. Alloys Compd. 2009, 485, L31-L34. [CrossRef]

57. Tong, C.J.; Chen, Y.L.; Chen, S.K.; Yeh, J.W.; Shun, T.T.; Tsau, C.H.; Lin, S.J.; Chang, S.Y. Microstructure characterization of $\mathrm{Al}_{\mathrm{x}} \mathrm{CoCrCuFeNi}$ high-entropy alloy system with multiprincipal elements. Metall. Mater. Trans. A 2005, 36, 881-893. [CrossRef]

58. Guo, S.; Ng, C.; Lu, J.; Liu, C.T. Effect of valence electron concentration on stability of fcc or bcc phase in high-entropy alloys. J. Appl. Phys. 2011, 109, 103505. [CrossRef]

59. Varalakshmi, S.; Kamaraj, M.; Murty, B.S. Synthesis and characterization of nanocrystalline AlFeTiCrZnCu high-entropy solid solution by mechanical alloying. J. Alloys Compd. 2008, 460, 253-257. [CrossRef]

60. Varalakshmi, S.; Kamaraj, M.; Murty, B.S. Processing and properties of nanocrystalline CuNiCoZnAlTi high-entropy alloys by mechanical alloying. Mater. Sci. Eng. A 2010, 527, 1027-1030. [CrossRef]

61. Davis, J.R.; Firm, K. Surface Engineering for Corrosion and Wear Resistance; Institute of Materials; ASM International: Materials Park, OH, USA, 2001; p. 279.

62. Ratia, V. Behavior of Martensitic Wear Resistant Steels in Abrasion and Impact Wear Testing Conditions; Tampere University of Technology: Tampere, Finland, 2015.

63. Ripoll, M.R.; Ojala, N.; Katsich, C.; Totolin, V.; Tomastik, C.; Hradil, K. The role of niobium in improving toughness and corrosion resistance of high speed steel laser hardfacings. Mater. Des. 2016, 99, 509-520. [CrossRef]

64. Lindroos, M.; Valtonen, K.; Kemppainen, A.; Laukkanen, A.; Holmberg, K.; Kuokkala, V.-T. Wear behavior and work hardening of high strength steels in high stress abrasion. Wear 2015, 323, 32-40. [CrossRef]

65. Sambyal, P.; Ruhi, G.; Mishra, M.; Gupta, G.; Dhawan, S.K. Conducting polymer/bio-material composite coatings for corrosion protection. Mater. Corros. 2017, 13, 1-16. [CrossRef]

66. Waara, P. Interview on 20.5.2016; SSAB: Stockholm, Sweden, 2016.

67. Bhaduri, D.; Penchev, P.; Dimov, S.; Soo, S.L. An investigation of accuracy, repeatability and reproducibility of laser micromachining systems. Measurement 2016, 88, 248-261. [CrossRef]

68. De Smith, M.J. Statistical Analysis Handbook; Drumlin Security Ltd.: London, UK, 2018; p. 638, ISBN 978-1912556076.

(C) 2019 by the authors. Licensee MDPI, Basel, Switzerland. This article is an open access article distributed under the terms and conditions of the Creative Commons Attribution (CC BY) license (http://creativecommons.org/licenses/by/4.0/). 